\title{
AS ESPÉCIES EXÓTICAS SOMOS NÓS: REFLEXÃOA A PROPÓSITO DO ECOTURISMO NA ILHA GRANDE
}

\author{
Rosane Manhães Prado \\ Universidade do Estado do Rio de Janeiro - Brasil
}

Resumo: Este trabalho analisa as implicações da introdução do turismo na Ilha Grande (Angra dos Reis, RJ), em especial para a população da Vila do Abraão, que foi abruptamente transformada num local de grande procura por parte de turistas e veranistas. Outros casos já estudados indicam um modelo das conseqüências da introdução do turismo em contextos nos quais ele antes não existia, o que é ilustrado com o caso do Abraão. Particularmente a questão da polaridade entre "nativos" e "não-nativos" aflora ali em razão da intensificação do turismo, correspondendo a uma barreira na aceitação de uma ideologia ambientalista e de propostas generalizantes para o que seria "um desenvolvimento turístico ideal".

Palavras-chave: ecologia, Ilha Grande, meio ambiente, turismo.

Abstract: This article analyzes the consequences of the arrival of tourism in Ilha Grande (Angra dos Reis, Rio de Janeiro), especially for the community of Vila do Abraão, that has been suddenly transformed into a spot for a mass of tourists. Different cases that have been equally studied suggest a model for the arrival and growth of touristic activities in places where these did not exist before, illustrated here with the case of Vila do Abraão. Here, the antagonism between "natives" and "nonnatives" becomes a central issue with the growth of tourism, hindering the incorporation of an environmental ideology and also the acceptance of general proposals for "an ideal touristic development".

Keywords: ecology, environment, Ilha Grande, tourism.

\section{Apresentação}

Chama a atenção, na literatura referente ao que se tornou o campo disciplinar do "turismo", de um lado, uma teoria desse campo, repleta de 
generalizações e proposições, e, do outro lado, o teor dos casos estudados, remetendo às incongruências das situações que ocorrem na prática. Por um lado, encontram-se colocações como:

O turismo "brando", ecológico, naturalista, personalizado e realizado em grupos pequenos de pessoas tende a caracterizar os fluxos turísticos do futuro. As atividades seletivas realizadas em equipamentos qualitativamente estruturados, tanto nos serviços prestados como em sua arquitetura e em seu tamanho, constituem o potencial dos movimentos turísticos para o próximo milênio. (Ruschmann, 2001, p. 17).

Dessa perspectiva ampla, "o turismo" é referido como se se tratasse de uma entidade com suas formas e contornos próprios. Fala-se de um contexto macro, em referência a tendências dominantes e a propostas como, por exemplo, de "planejamento sustentável do turismo", de "controle da capacidade de carga", de "turismo popular social", que, ao mesmo tempo que soam como avaliações/constatações, soam também como prescrições/ proposições ideais. E por outro lado, de uma perspectiva mais focada, encontram-se os muitos estudos de caso mostrando os percalços na concretização de tais propostas e as incompatibilidades entre elas, seja quanto aos visitantes turistas, seja quanto aos seus receptores.

Aquelas colocações e recomendações de perspectiva ampla são baseadas em situações já observadas e cujos aspectos negativos se pretende que sejam evitados. Veja-se, por exemplo, a receita de Krippendorf (1977, p. 86146 apud Ruschmann, 2001, p. 70), numa lista de "23 sugestões que, se aplicadas integralmente, conduzirão a um desenvolvimento turístico ideal", e pelas quais podem ser claramente inferidos os problemas a serem evitados. Ocorre, no entanto, que tais recomendações, quando retornam da teoria para a prática, quando migram dos estudos para as propostas de intervenção em diferentes contextos, tornam-se premissas para um planejamento que chega atrasado, que "era para ter sido feito e não foi" para fazer face à "chegada do turismo", como dizem aqueles que em tal processo se vêem envolvidos. E aí o que se tem são as recomendações para "o ideal" de um lado, e, do outro, os fatos consumados de um caminho já percorrido conforme um modelo perverso.

$\mathrm{O}$ que apresento aqui pode ser considerado como um daqueles estudos de perspectiva mais focada, no sentido de mostrar as implicações da implantação do turismo num determinado contexto, que é o da Ilha Grande (o que 
vem significando, como vem sendo traduzido o "turismo" na Ilha Grande, em especial para a população da Vila do Abraão, que foi abruptamente transformada num local de grande procura por parte de turistas e veranistas) e as dificuldades de aplicação das propostas para o que seria "um desenvolvimento turístico ideal", em face de peculiaridades do contexto local.

$\mathrm{O}$ que quer que se deseje pesquisar e entender da vida na Ilha Grande hoje, há que se considerar esse componente que é "o turismo". Assim, em razão de uma pesquisa que venho desenvolvendo a partir de 1999 sobre a percepção de "questões ambientais", ao vivenciar o que se passava ali, e sobretudo no Abraão, fui logo levada a pensar sobre toda uma problemática referida às "questões do turismo". E ao mesmo tempo em que recorria a alguns trabalhos desse campo temático, eu ia percebendo o paralelismo entre as situações referidas nesses estudos e o que se pode ver no Abraão. Os casos já registrados e analisados e aquilo que se observa na Vila do Abraão indicam um modelo das implicações do turismo em determinados contextos nos quais ele antes não existia. O que faço a seguir é mostrar como a Ilha Grande preenche esse modelo; como certas questões afloram ali em torno do "turismo", particularmente aquela que diz respeito à polaridade entre nativos e não-nativos, interferindo fortemente nesse campo e na sua correlação com as questões ecológicas.

\section{A llha Grande como ilustracão do modelo perverso da "chegada do turismo"}

Antes de traçar o paralelo, mostrando os pontos em que a Ilha Grande ilustra esse modelo das repercussões da implantação repentina das atividades turísticas, façamos sobre a Ilha uma panorâmica.

$\mathrm{Na}$ "história da Ilha Grande" repercutiram todos os ciclos econômicos reconhecidos na "história do Brasil", com a formação do que se considera como a cultura caiçara ${ }^{1}$. E no último século a Ilha esteve marcada por duas atividades às quais toda a população estava referida, e que eram: a pesca

\footnotetext{
1 "Caiçara" é o termo pelo qual se designa o modo de vida dos nativos de uma faixa do litoral brasileiro. Assemelhando-se ao uso do termo "caipira", aplicado para certos segmentos de uma região do interior, a idéia de caiçara refere-se a uma economia voltada para a subsistência, que inclui roça e pesca, e corresponde a marcas culturais peculiares (para maior aprofundamento, ver Adams, 2000; Calvente, 1997; Diegues, 1998). Na Ilha Grande, "caiçara" é também o termo utilizado para aqueles que se consideram os "verdadeiros" nativos da Ilha.
} 
e as instituições carcerárias situadas nas vilas do Abraão e Dois Rios e simbolicamente condensadas na prisão da Vila Dois Rios, referida por todos como "o Presídio", com o qual a Ilha era freqüentemente equacionada. Com a grande redução da atividade pesqueira a partir da década de $70^{2}$, e com a extinção do presídio na década de 90 , o turismo vem se consolidando como a atividade econômica mais importante do lugar (Mello, 1987).

Muito eloqüentes e expressivas da mudança do eixo econômico da atividade da pesca para o eixo econômico da atividade do turismo na Ilha, são algumas das antigas fábricas de sardinha hoje transformadas em pousadas, que podem ser vistas nas diferentes praias da face da Ilha voltada para o continente. Fisicamente adaptados e apropriados a uma nova função, os simpáticos prédios com um padrão arquitetônico todo peculiar indicam concretamente essa passagem: da pesca ao turismo. Mas em correlação com tal passagem, deve ser considerado um fato mais recente, e marcante na vida da Ilha Grande, que foi, em 1994, a desativação seguida da implosão "do Presídio" - o Instituto Penal Cândido Mendes, situado na Vila Dois Rios, e que ali existia desde 1903 -, fato esse visto pela maioria dos moradores e frequientadores da Ilha como responsável por uma grande intensificação do turismo. Embora se possa discordar dessa equação direta da desativação do presídio com o aumento do turismo (Wunder, 2000), na visão local existe um consenso sobre a questão, atribuindo-se à eliminação do presídio não só o que se diz ser essa "explosão" do turismo, como também o que se diz ser a exposição da Ilha a uma verdadeira "invasão".

Outra marca recente da Ilha é o fato de corresponder a diferentes unidades de conservação, criadas a partir da década de $70^{3}$. Nesse sentido é que, sendo em grande parte considerada como área de proteção ambiental, e uma vez liberada da sombria e restritiva presença do presídio, a Ilha passa

\footnotetext{
2 Tal redução da pesca comercial se deu a partir da década de 70 em função de diferentes processos concomitantes e correlacionados, tais como: a pressão de grupos externos de pesca industrial de grande porte; a redução dos mananciais; o fechamento das fábricas de sardinha locais; a criação das unidades de conservação; a expulsão dos caiçaras pela especulação imobiliária. Hoje, das diversas comunidades/praias da Ilha, apenas a de Provetá vive da pesca, sabendo-se que os donos de barcos também se dedicam ao trabalho com traslado de turistas nas épocas propícias.

${ }^{3}$ A Ilha Grande - que abriga todos os sistemas característicos da mata atlântica - corresponde a várias Unidades de Conservação, criadas a partir da década de 70, através de diferentes legislações e geridas por diferentes instâncias governamentais: APA Tamoios, Parque Estadual da Ilha Grande, Reserva Biológica da Praia do Sul, Parque Estadual Marinho do Aventureiro.
}

Horizontes Antropológicos, Porto Alegre, ano 9, n. 20, p. 205-224, outubro de 2003 
a ser representada pela idéia de um "paraíso ecológico" a ser visitado e usufruído, mas também preservado. Naturalmente que é nessa idéia que se funda o apelo turístico para o lugar, como se pode ver nos folhetos de divulgação e nos sites referentes ao lugar. O turismo aí, portanto, só deveria ser o que se entende como ecoturismo.

Esse é o quadro em que podemos ver a Ilha Grande, onde a cultura caiçara originária veio a coexistir com uma economia baseada na pesca para comercialização (décadas de 30 a 70); com a implantação de unidades de conservação impondo uma série de restrições em termos da ocupação e uso do território (a partir da década de 70); com a presença de presídios e de uma cultura policial, que passou a equacionar-se com a Ilha (do final do século XIX até a década de 90). Essa sucessão culmina com a guinada brusca para o turismo, que se deu na década de noventa, relacionada com a desativação do presídio, como exposto acima. Também a presença da Universidade do Estado do Rio de Janeiro na Ilha Grande está relacionada à implosão do presídio, na medida em que, a partir desse evento, o Estado do Rio de Janeiro cedeu para a UERJ, através de um termo de cessão de uso, pelo prazo de cinqüenta anos, a área antes ocupada pela instituição penal. Nessa cessão estabeleceram-se vários compromissos, entre os quais a instalação de um centro de estudos ambientais, o desenvolvimento de pesquisas, a criação e manutenção de um museu.

Nesse quadro, se a passagem "do presídio ao turismo" é, na visão de muitos, um eixo explicativo para o que vem ocorrendo na Ilha, a Vila do Abraão - a "capital da Ilha", onde aportam e de onde saem as barcas de passageiros em conexão com Angra e Mangaratiba - parece condensar as repercussões desse fato. É uma Ilha agora vista como "exposta", "invadida". Há o caso dos caiçaras que saíram, expulsos de diferentes praias pela especulação imobiliária, e há o caso dos que ficaram e tentam adaptar-se e tirar proveito da nova situação; mas é na Vila do Abraão que são reconhecidas com mais clareza as traduções daquela eclosão, naquilo que alguns consideram como um Abraão literalmente "detonado".

Vejamos então os principais itens do modelo da entrada repentina do turismo, no caso da Ilha Grande representada pela Vila do Abraão, em comparação com alguns outros casos e focalizando sobretudo as mazelas que afetam a população receptora. O Abraão parece ter-se enredado numa situação que representa aquilo que as outras comunidades da Ilha não querem ser. Ali, não só tem se fixado uma boa parte dos recém-chegados 
interessados na atividade econômica do turismo, mas também é onde se hospedam e por onde quase que necessariamente passam os muitos turistas que vêm visitar a Ilha. Paira no ar um medo de que o Abraão vá "virar uma Angra" (Angra dos Reis, a cidade-sede do município, tida como o exemplo de urbanização a mais precária e desorganizada) e de que as demais praias vão "virar o Abraão", esse que ninguém quer ser, com tal afluxo de gente, com as mudanças que descaracterizam. Diz-se que o número de pousadas era de meia dúzia há apenas alguns anos, e que agora está em torno de oitenta, e sempre mais algumas podem ser vistas em construção ${ }^{4}$.

Nesse contexto, o aspecto-mor a se reconhecer do modelo perverso da implantação do turismo é a forte mudança no modo de vida local, que na verdade engloba todos os demais componentes do modelo. Trata-se de um processo abrangente e de muitas implicações, como se pode ver nesta avaliação de Luchiari (2000) a propósito do litoral norte paulista:

Dos anos 80 para cá, em decorrência sobretudo da implantação e da pavimentação da BR-101 (Rio-Santos), a atividade turística passou a modelar a paisagem, a acelerar o processo de urbanização e especulação imobiliária, a mudar o perfil demográfico com o incremento migratório,e, somado às políticas de preservação dos recursos naturais do Parque Estadual da Serra do Mar, passou também a ser responsável pelo processo de marginalização, ou mesmo expulsão, das comunidades caiçaras. (Luchiari, 2000, p. 136).

Lembremos que a Ilha Grande reúne as mesmas características de várias outras localidades estudadas em relação à "chegada" do turismo: a imagem paradisíaca, o contexto de unidade de conservação ambiental, o apelo ecológico. É o caso do litoral norte paulista na situação acima referida por Luchiari (2000), como também o das ilhas do litoral paulista, tratado por Furlan (1997), ou, especificamente, o de Ilhabela, tratado por Calvente (1997), Saco de Mamanguá, em Parati (RJ), estudado por Diegues e Nogara (1994) e Praia do Forte, na Bahia, estudada por Lorenzo (1996) e Gomes, L. (2000). Os autores desses outros casos semelhantes referem-se a um confronto de

${ }^{4}$ Segundo listagem da Prefeitura de Angra dos Reis, em 2002 eram 65 as pousadas existentes na Vila do Abraão. 
saberes e de lógicas: "uma ruptura com os modos anteriores de vida, pesqueira e camponesa". "Tal realidade significou a imposição de uma outra lógica na dinâmica socioambiental e cultural." (Gomes, L., 2000, p. 173). O cerne do que estou aqui designando amplamente como "mudança no modo de vida local" diz respeito aos padrões culturais locais atravessados por uma nova lógica econômica, ditada pela introdução do turismo. A repercussão disso se dá em diversos níveis que se encadeiam, como se fossem corolários uns dos outros, seguindo um modelo que pode ser assim esquematizado:

1. mudanças drásticas na ocupação do território e no uso dos recursos naturais:

a. proibições e interdições no caso de áreas protegidas;

b. deslocamento dos nativos de seus locais originais (expulsão, internalização, segregação espacial).

2. destruição do objeto de atração:

a. especulação imobiliária;

b. densificação e excessos de todo tipo (gente, demandas, serviços, construções);

c. problemas de infra-estrutura;

d. problemas de regulamentação;

e."o lugar não é mais aquele".

3. ambigüidade em relação ao turismo:

a. perplexidade da população nativa;

b. é bom- é a vocação do lugar, traz divisas;

c. é ruim- sentimento de invasão (o mal que vem de fora).

4. conflitos/confrontos de interesses e valores entre grupos diversos

a. diversos segmentos disputando espaço econômico, político, social, cultural

b. nativos $\mathrm{X}$ não nativos

- marginalização dos nativos

- disputa por território e trabalho com os novos moradores (empregados e empresários do turismo)

- disputa de valores

$\mathrm{Na}$ Vila do Abraão, na Ilha Grande, podemos ver uma atualização desse esquema. O turismo ali deveria ser o ecoturismo - é o que defende um certo segmento de pessoas interessadas nos destinos da Ilha: ambientalistas, técnicos dos órgãos de controle ambiental, alguns empresários do turismo, os veiculadores de uma proposta de consciência ecológica. 
Mas, a exemplo de outros casos conhecidos de "paraísos", rotulados ou não como ecológicos (dos quais talvez Búzios, no Estado do Rio, e a região de Porto Seguro, na Bahia, sejam os mais notórios), isso pode significar uma incongruência, o mesmo se podendo dizer da pretensão de se juntar turismo com preservação - no sentido de que, não havendo o delicado controle e o planejamento que a situação demanda, o que acaba acontecendo é a destruição do objeto de atração e/ou de preservação (Lorenzo, 1996).

Uma observação que qualquer um pode fazer em relação à Vila do Abraão é que ela parece ao mesmo tempo uma agência imobiliária - com um anúncio a cada passo, de aluguel "por temporada" de casas, quartos, "quitinetes"; ou placas com os preços das diárias dos campings e das pousadas - e um canteiro de obras - com construções, na maioria de dois andares, igualmente encontradas a cada passo ao longo de todos os percursos da vila. Se, de um lado, há sempre uma construção nova ou acréscimos nas casas e pousadas já existentes, indicando nitidamente uma expansão que abrange ricos e pobres, nativos e não-nativos -, por outro lado, nas colocações de muitas pessoas de diferentes segmentos sociais aparece uma preocupação com tal expansão: "alguém tem que dar uma trava"; "chega de pousada"; "tem que congelar".

Por trás dessa preocupação estão vários fatores, um dos quais é o reconhecimento, ligado à questão referida acima, da destruição do próprio objeto de atração, no sentido de que tal quantidade de prédios, vários deles com dois pavimentos, já vem gradativamente comprometendo a paisagem bucólica da vila. Outro é o que correlaciona o aumento das possibilidades de hospedagem com a perspectiva do aumento correspondente de visitantes, que o lugar "não suporta". Outro fator ainda da preocupação, e que se encadeia com os anteriores, traduz-se na idéia de que "antes era melhor" que também se pode ler como "no tempo do Presídio era melhor" - com duas conotações principais e igualmente correlacionadas: era melhor porque "era mais seguro", o presídio garantia; e era melhor porque "a Ilha era mais Ilha", não entrava nem ficava tanta gente, eram pessoas e costumes só dali. A idéia de que "no tempo do Presídio era melhor" é como uma vinheta, ou uma pontuação que se ouve todo o tempo entre os moradores da área de Abraão e Dois Rios, com esse mesmo sentido da segurança que consideram que aquela instituição penal plantada ali oferecia. Isso é algo previsível de se escutar nas conversas e nas entrevistas sobre a vida local (Gomes, M., 2001; Prado, 2000; Sousa, 2002), complementado com comentários no senti- 
do de que não se tinha medo dos bandidos que fugiam da prisão como se tem hoje desses - "qualquer um" - que podem chegar e entrar sem controle nenhum. É o que se pode ver nas seguintes referências irônicas: "Antes eles [os bandidos] vinham obrigados e queriam sair a qualquer custo. Hoje, eles vêm espontaneamente e não querem sair de maneira nenhuma". "O Presídio segurava. Ao preso desconhecido a Ilha Grande agradece". Assim, o que se diz, em última instância, é que o presídio garantia não só a ordem e a segurança como também a preservação da Ilha, que não era tão assediada.

Os problemas se exacerbam nos feriadões, Ano Novo, Carnaval, Semana Santa, e na alta temporada do verão, e que pude presenciar em sucessivos janeiros. Essa guinada no Abraão em função do turismo se deu sem qualquer planejamento ou ordenamento - isso é o que agora todos reconhecem e querem consertar, ao mesmo tempo em que, paradoxalmente, continuam seguindo em frente dentro desse esquema atropelado. Acumulam problemas de toda ordem, desde questões de infra-estrutura que atingem igualmente a todos, até questões que são objeto de disputas entre os diferentes segmentos sociais que ali interagem, em razão das respectivas posições em relação à demanda turística e diante de uma lógica do lucro que parece que toma conta de tudo. E essa lógica do lucro também se exacerba naquelas ocasiões de pico, quando cada um quer "ganhar o seu". O Abraão fica parecendo um grande comércio desvairado - "tudo virou dinheiro", reclama um morador - e o verão é a hora de todo mundo defender o seu; tudo se vende, tudo se aluga, enquanto um acúmulo de lixo vai se formando. Os chamados ambulantes, com os quais a fiscalização do parque e da prefeitura vive a lutar, essa é a hora deles; postam-se nos lugares onde há mais demanda daquilo que oferecem: água, cerveja, refrigerantes, biscoitos... para matar a sede e a fome de tanta gente perambulando na Ilha no calor de janeiro; imagine-se no Carnaval. Também uma parte do comércio estabelecido tende a desrespeitar os regulamentos quando, por exemplo, avança sobre os espaços da rua com suas mesas e cadeiras. Há discórdia quanto ao barulho da música até tarde em lugares de diversão mais afastados do centro e próximos de pousadas, que pretendem o sossego para seus hóspedes. Também os barqueiros de passeio podem se desentender pelo desrespeito de alguns aos acordos do grupo. A impressão que se tem é de que todos estão disputando com todos, em face de regras que não funcionam e de pacto que não conseguem fazer ou sustentar. É um Abraão denso e tenso, muito ao contrário daquele apelo do paraíso ecológico - o parque logo 
ali do lado, as trilhas para as tantas praias, a beleza luminosa - para o qual seria a porta de entrada, e muito ao contrário daquele apelo de NO STRESS das camisetas vendidas aos turistas.

Tudo isso se relaciona com a visão dos nativos e dos freqüentadores mais antigos da Ilha, no sentido de que "a Ilha não é mais a mesma", lembrando-se de que é comum as pessoas se referirem às respectivas localidades na Ilha como "a Ilha". Assim, os que dizem no Abraão que "a Ilha não é mais a mesma" estão se referindo mesmo ao Abraão, que, na verdade, tornou-se um lugar cosmopolita, com cybercafés e restaurantes com cardápio em inglês. O turismo, que é a fonte disso tudo, é encarado de maneira ambígua, na medida em que, se de um lado a ele se atribui toda a mudança da vida local da qual as pessoas sentem falta, de outro lado é valorizado porque "trouxe emprego". Assim, ao lado da nostalgia por um outro tempo e das reclamações em relação a essa "invasão" da Ilha, que são mais expressadas pelos moradores antigos adultos e os mais velhos, aparecem também colocações no sentido de valorizar o que o turismo oferece de oportunidade para todos. Um antigo morador sintetiza em sua fala: "Aquele rio, nadei ali" - ele se refere a um dos riachos que cortam a vila, hoje transformados em verdadeiros valões poluídos e cheios de lixo - "A Ilha toda cresceu muito... não está preparada pra tanta gente... Se alguém não der uma trava... Cresceu, deu emprego, mas está na hora de parar. Cachoeira acabou... Você não vê mais morador da Ilha, tudo é novo. Não pode deixar construir mais pousada."

Note-se que no discurso nostálgico desse morador estão indicados muitos dos componentes da questão da mudança brusca que sofreu a localidade, e inclusive um ponto que considero que se destaca no caso da Ilha Grande, que diz respeito à polaridade entre os "nativos" e os "não-nativos". A menção ao fato de que "agora tem mais gente de fora do que da Ilha", "cadê os nativos?", "agora a maioria do povo do lugar é de fora", "a gente não sabe mais quem é quem", assim como aquela referente ao fato de que "o tempo do Presídio era melhor", é outra vinheta para o discurso dos moradores da área de Abraão e Dois Rios. Mas quem são afinal os nativos, cuja designação e significado parecem ganhar tanto relevo nesse contexto do Abraão que tentei brevemente caracterizar até aqui? É o que veremos em seguida.

Nesta caracterização, vimos como a Vila do Abraão na Ilha Grande ilustra o modelo de uma introdução abrupta do turismo, abstraído de outros casos analisados e com o qual o caso da Ilha dialoga - todo o processo da Ilha é muito semelhante àqueles apresentados nos diversos estudos aos quais 
me referi no início deste item, podendo-se dizer que, no conjunto, são variações de um mesmo fenômeno. Mas a seguir mostrarei um ponto específico que julgo ter uma expressão mais significativa no caso da Ilha. Trata-se da polaridade entre nativos e não-nativos, que será vista ao mesmo tempo em que se retoma o ponto colocado inicialmente sobre as proposições fundadas numa "razão ecológica", que alguns encaminham "para o bem de todos".

\section{Nativos e não-nativos: um aspecto que se destaca}

A questão das relações entre a população local e os migrantes e novos freqüentadores do lugar em função da introdução do turismo - freqüentemente com desvantagem para uma parte ou a totalidade da população original - que é um dos componentes do modelo referido no item anterior, no caso do Abraão parece constituir a questão mais exacerbada, e que engloba as demais. A polaridade entre "nativos" e "não-nativos" é uma marca estrutural e estruturante do modo como se percebem os moradores da Ilha Grande, e do modo como são levados a perceber aqueles que ali vêm a conviver, como já demonstrei em outros trabalhos, que aqui retomo (Prado, 2002, 2003, no prelo). Penso que, embora a classificação nativos versus não-nativos possa ser rastreada para trás na história da Ilha Grande, ela adquire um peso e uma significação especiais nesse contexto mais recente de ênfase no turismo ${ }^{5}$. E nesse sentido, de novo, a Vila do Abraão é a localidade da Ilha que parece ilustrar mais claramente os diferentes aspectos de manifestação dessa classificação.

Já deve ter ficado claro que, quando digo aqui "nativo", não estou me expressando como nós antropólogos costumamos falar genericamente dos grupos pesquisados, referindo-nos à "visão nativa", às "categorias nativas" daqueles que em qualquer contexto são o nosso objeto de pesquisa. Assim, com ou sem trocadilho, pode-se dizer que, no caso aqui considerado, "nativo" é uma categoria nativa; naturalizada portanto, e referida com freqüência no discurso das pessoas. Tem um peso e uma significação muito importantes na vida local, correspondendo a um eixo classificatório igualmente importante.

\footnotetext{
5 Não tenho a intenção de reconstituir uma história dessa questão, nem genericamente reconhecendo que é um tema clássico na antropologia o tema do "outro", perante o qual os grupos humanos se defendem e se definem - nem na Ilha Grande, mas sim de considerá-la a partir das transformações recentemente ocorridas na Ilha.
} 
Como toda categoria que diz respeito à identidade social, essa também é acionada contextualmente em função de uma contrastividade (em relação a quem se vê como não-nativo), sendo referida a valores (o que significa ser nativo) e atributos (o que caracteriza os nativos); e, no caso, recobre gradações e hierarquizações no sentido de se ser "mais" ou "menos" nativo, o que implica mais ou menos peso e prestígio em determinada situação. Nessa gradação se poderia dizer, com muitas aspas, que a condição "mais nativa" no imaginário local corresponde aos "caiçaras", que são vistos como os verdadeiros nativos da Ilha - também às vezes romanticamente referidos como representando a Ilha do jeito que ela era e que devia ser - e cuja designação é freqüentemente usada como sinônimo mesmo de nativo. Para a outra ponta, a dos não-nativos, é mais difícil de definir a categoria correspondente, mas a polaridade parece mais eloqüente em relação aos "pousadeiros" e outros empresários do turismo que vieram de fora - sobretudo os que vieram mais recentemente - e se estabeleceram ali com um poder econômico de vários graus.

"Ser da Ilha" pode ser mencionado como uma forma de legitimação em certos contextos; por exemplo, em reuniões públicas para tratar de assuntos de interesse coletivo, quando se poderá ouvir uma autoridade vinda de Angra dizer: "sou nascido na Ilha, minha família é ali do Saco do Céu", ou "minha família vive aqui há mais de cem anos". Do outro lado se poderá ouvir alguém como que se desculpando: "Eu não minto, nasci em Quintino", e sobre quem não tem a mesma sinceridade: "Esse cara diz que é daqui, que quer defender os interesses da Ilha, mas é nada, veio lá de Resende". Assim, é quem se sente como sendo da Ilha que expressa em seu discurso os indicadores sobre os outros que não o seriam: "Uma gente que veio vindo, que não é da Ilha e vai ficando e que agora é a maioria - por isso que a Ilha mudou, por isso que a Ilha perdeu o jeito de Ilha." Entre essa gente que "veio vindo e foi ficando", e que pertence a segmentos diferentes daquele dos empresários do turismo, estão, por exemplo, os "peões nordestinos", que vêm como mão-de-obra para as tantas construções, os "hippies" artesãos, e os muitos que vêm se empregar nos diversos estabelecimentos comerciais.

Também os policiais são, nesse contexto, uma espécie de nativo. Com o peso simbólico do presídio na Ilha Grande - com a qual foi por muito tempo equacionado, e para a qual é uma marca identitária forte -, ser vinculado ao presídio é como ser da Ilha. É o caso dos antigos policiais, hoje aposentados, e daqueles que, tendo trabalhado no presídio, continuam na 
ativa, todos morando no Abraão desde "o tempo do Presídio", uma boa parte dos quais pertence de fato a famílias da Ilha, por descendência ou por casamento. Esse segmento - que tem uma visibilidade extra, por ter permanecido ocupando as mesmas casas do Estado destinadas aos funcionários, que um dia foram ou ainda são, do sistema penitenciário, numa área do Abraão referida como "a Vila" - também se opõe aos "de fora", como qualquer nativo faz.

Há ainda aqueles, muitos, que se consideram nativos porque já vivem na Ilha há tanto tempo e porque adotaram a Ilha, sentindo-se também adotados por ela: "Eu posso me considerar nativo, já vivo aqui há tanto tempo", algo que, como se pode imaginar, é perfeitamente passível de ser acionado como uma afirmação, da mesma maneira que pode ser igualmente questionado, conforme a situação.

Como se vê, entre ser "nativo" ou "não-nativo", existem muitas maneiras de as pessoas se colocarem. E podem também ser constatadas algumas superposições de categorias de um lado e do outro, envolvendo inclusive uma questão de classe: "nativos"/"pobres"/empregados/tradição local, de um lado; "não-nativos"/"ricos"/patrões/ambientalistas, de outro lado. É importante observar que isso é uma configuração dominante no plano das representações e que tem uma eficácia simbólica forte. É claro que há muitos "nativos" que são bem de vida e empresários do turismo; do mesmo modo que há muitos "não-nativos" que são pobres e empregados do turismo. Poder-se-á também verificar que praticamente a metade das pousadas de porte do Abraão, bem como boa parte dos estabelecimentos comerciais, pertence a famílias locais. Sabe-se, ainda, que há ambientalistas com as mais variadas posturas. Contudo, se perceberá que, ao serem emitidos os discursos de antagonismo, é aquela equação de categorias que será acionada.

Entre os episódios e situações que ilustram a polarização e o modo como os nativos se colocam e/ou são vistos como refratários estão as constantes acusações e queixas de parte a parte. "Eles não se interessam, são fechados, não adianta a gente propor nada", dizem os de fora, e mais: "O Abraão é isso: todo mundo cobra muito mas ninguém participa... Eles olham diferente para os de fora mas não querem fazer nada; só botar aquela barraquinha ali no quintal e ganhar um dinheirinho". Do outro lado, os nativos reclamam por serem ignorados e desconsiderados, equacionando-se por vezes com uma posição social desfavorecida: "a cabeça dos grandes tem que pensar mais nos caiçaras e menos nos bolsos deles mesmos... falta olharem mais para a comunidade e menos para o turismo"; "acho que favorecem um grupo: classe média, classe alta; parece que os pobres estão esquecidos". 
Há também indicadores que permitem perceber essa polarização na vida cotidiana $^{6}$, e um desses indicadores - com o qual voltamos ao nosso tema de fundo - pode ser o modo como as pessoas se manifestam a propósito do "tipo de turismo" que se quer, o que leva a posturas diferentes tanto entre os nativos como entre os não-nativos. Observa-se, por exemplo, uma clivagem clara no sentido de que, de um modo geral, da parte dos empresários do turismo que vêm de fora - sejam pousadeiros, barqueiros ou donos de outros estabelecimentos comerciais -, há uma cobrança de "profissionalismo" que eles querem exercer e que demandam igualmente dos nativos, enquanto que estes estão interessados em adaptar-se da melhor maneira possível, tirando proveito do jeito que for melhor para encaixar seus recursos e suas capacidades, mediante as suas próprias necessidades nesse contexto.

Aqui sobretudo - nesse aspecto tão básico da vida local, que é a relação com o turismo - pode-se ver a conexão com os temas ecológicos, em torno dos quais a polaridade entre nativos e não-nativos se torna bastante eloqüiente. Nesse contexto que é visto de várias maneiras como de assédio à Ilha Grande, há uma clara disputa dos atores presentes - moradores, freqüentadores, ONGs ambientalistas, órgãos públicos ambientais, as universidades - em torno de uma mobilização para "salvar a Ilha". As diferenças ficam por conta de salvar por que, para que, para quem.

Essa situação pode ser vista como um caso de estabelecidos e outsiders no sentido em que Elias e Scotson (2000) registraram no seu trabalho, sendo que, no Abraão, ao contrário do caso analisado por esses autores, de um modo geral, os "estabelecidos" - que têm um diferencial de poder a seu favor - são os que vieram de fora, os que chegaram recentemente e se instalaram como empresários do turismo, enquanto que os outsiders - os excluídos do poder - são os nativos/moradores antigos, que se tornaram empregados do turismo. Mas, ao que parece, os "nativos" do Abraão reagem com um outro poder - com fortes repercussões simbólicas e práticas - que é o de se manterem impermeáveis ou resistentes às tentativas "civilizatórias" dos "de fora". Afinal quem entende do paraíso? Quem vai dizer o que é bom para a Ilha?

\footnotetext{
${ }^{6}$ Como, por exemplo: em certos contextos quem fala "eles" e "nós"; quem, e de que maneira, está presente nos cultos religiosos locais (acompanhando a procissão de São Sebastião e se cumprimentando com intimidade na hora do ritual da "paz de Cristo" na missa; exercendo a sociabilidade propiciada pela freqüentação aos cultos evangélicos); quem adora ir aos bingos promovidos para angariar fundos em diferentes situações; quem organiza a Festa das Três Bocas - programada e realizada de modo a não ser explorada como apelo turístico - e quem vai lá.
}

Horizontes Antropológicos, Porto Alegre, ano 9, n. 20, p. 205-224, outubro de 2003 


\section{Espécies exóticas}

Por trás dessa questão da polaridade entre nativos e não-nativos na Ilha Grande está uma outra questão, que é a do confronto entre diferentes sistemas de valores, e pode-se entendê-la e encará-la pelo caminho que nos oferece a perspectiva antropológica, partindo do plano simbólico e da produção e negociação de significados. Nesse sentido, essa polaridade e a conseqüiente resistência dos nativos em incorporar os padrões ditados pelos não-nativos podem ser entendidas como um elemento do esquema cultural local (nos termos de Sahlins, 1981), que aflora com força no contexto da introdução do turismo e de uma ideologia ecológica. Sahlins $(1992,1997)$ nos mostra de maneira instigante como diferentes povos se apropriaram a seu modo das "imposições" do mercado, transformando-as, fazendo uso delas conforme seus valores e "interesses" demarcados culturalmente, e "devolvendo-as" - se não confrontando, afrontando o sistema do modo mais inusitado.

Um paralelo também poderia ser feito com aquilo que o velho contador de histórias da tribo africana diz à antropóloga Laura Bohannan, depois do percurso estressante que ela faz tentando contar aos nativos a história de Hamlet, que se pretendia ter sentido universal. Depois de o grupo de ouvintes virar do avesso a história de Hamlet, mudando os significados de cada episódio, desautorizando a cada passo as explicações e justificativas por ela apresentadas, ou seja, construindo uma outra história, o velho nativo lhe diz: "Você precisa nos contar mais histórias de seu país. Nós que somos mais velhos a instruiremos sobre o real significado dessas histórias, de modo que, quando você voltar à sua terra natal, os anciãos verão que você não esteve apenas sentada à sombra de um arbusto, mas sim, entre aqueles que sabem das coisas e lhe ensinaram sabedoria" (Bohannan, 1967). Um antigo morador da Vila Dois Rios, na Ilha Grande, me disse: "Depois que entrou o 'Imbamba', estragou tudo." Essa colocação, que expressa muitas coisas, foi feita a propósito de uma questão muito presente nos casos de lugares que se transformaram em áreas de preservação ambiental ou unidades de conservação ambiental, e que diz respeito ao rigor da aplicação das leis de proteção tendo como alvo as "populações tradicionais". "Imbamba" nessa fala nativa quer dizer "Ibama" - a sigla referente ao nome do órgão de controle ambiental de âmbito federal que tem sua presença disseminada por todo o país -, e ilustra sugestivamente as traduções e nuances que o som dos termos desse campo da "ecologia/meio ambiente" e os seus significados adquirem nas visões locais. 
Na pesquisa já realizada na Ilha pude perceber diferentes reações à legislação ambiental. Entre outras visões, esta reflete uma clara reação ao que localmente se vê como um excesso, ou um absurdo, nas exigências dos órgãos de controle ambiental no que se refere à população local. No seu modo de ver, dependendo do caso, "pode" - caçar, tirar um palmito, um carrinho de areia, cortar um pau, pescar. O critério é a necessidade, a pobreza dos nativos, que "realmente precisam" e não vão comercializar. No caso, estamos diante de dois códigos de relacionamento com a natureza: o tradicional/local e o da ideologia ambientalista de proteção. E os nativos parecem querer dois pesos e duas medidas diante da legislação ambiental, para eles devendo valer os fundamentos do seu código local.

Entre os diferentes sistemas de valores e interesses diante dos quais se vêem os nativos da Ilha Grande, está esse que estou chamando de "ideologia ambientalista" - por sua vez também já trazendo muitas nuances e passando por várias instâncias, como a própria legislação, os órgãos de controle ambiental e os grupos ambientalistas - a partir da qual se pretende "civilizar" os nativos. Pode-se aqui fazer uma analogia com os muitos casos de "populações tradicionais" afetadas pela transformação de seus lugares em unidades de conservação, nos quais, para além da perplexidade dos habitantes originais, surge um inescapável conflito de visões e interesses entre estes e o Estado que cobra o cumprimento da legislação ${ }^{7}$. Como costuma acontecer naqueles casos, também na Ilha, na percepção de boa parte dos ambientalistas, as visões nativas em geral são consideradas como uma "nãoecologia", isto é, como uma "ausência de", ao invés de "a presença de uma ecologia nativa" (uma "etnoecologia"), ou de uma visão peculiar. Assim é que os nativos da Ilha, de um modo geral, também reagem, em princípio sendo refratários "à ecologia" (muitas vezes referida como uma entidade, uma coisa que chegou).

Assim como essa perspectiva "ecologizante" trazida de fora a partir de uma determinada conjunção de fatores, a propósito da introdução e da intensificação do turismo na Ilha Grande, muitas outras visões são trazidas. Algumas destas até convergem, juntando ecologia e turismo, como é o caso da proposta de ecoturismo, que se julga mais que apropriada num contexto

7 São muitos os casos estudados; ver, por exemplo, Diegues (1998), Diegues e Nogara (1994), Furlan (1997), Gomes, L. (2000), Lorenzo (1996) e Luchiari (2000). 
de unidades de conservação. No caso da Ilha, além do que seria a preservação e proteção num sentido amplo, a lei demanda proteção integral quando se trata ali das áreas de "parque" e de "reserva". Assim é que, entre as muitas preocupações dos técnicos sobre o assunto, está aquela que diz respeito às "espécies exóticas", também referidas como "espécies invasoras". Estamos agora falando do meio ambiente natural; trata-se, por exemplo, das plantas e animais provenientes de um ambiente e que são introduzidos em outro, podendo causar desequilíbrio e danos ao novo ambiente em que são inseridos. Na Ilha Grande, é famoso o caso dos "micos-sagüis", responsáveis pela diminuição da variedade e do número de pássaros (porque se alimentam dos ovos); em tempos recentes se enfrenta o caso do "caracol africano", que devora tudo que encontra e não tem predador.

Cuidados, muitos cuidados são recomendados nesse sentido. A UERJ, que tem um campus na Ilha abrigando um Centro de Estudos Ambientais e Desenvolvimento Sustentável, desenvolve um grande número de pesquisas que recobrem tais questões no campo da biologia/ecologia. Nas reuniões desse Centro, quando vejo meus colegas biólogos se debatendo em candentes e serí́ssimas discussões (tendo mesmo sido criada uma Comissão de Espécies Exóticas para estudar os diversos casos) e quando vejo ao mesmo tempo, tanto nas nossas reuniões como em outras de diferentes entidades que pretendem trazer soluções para os problemas da Ilha Grande, o modo como os nativos são referidos dentro daquele esquema de quererem educálos e civilizá-los ecologicamente - não resisto a pensar que, para esses mesmos nativos, nós é que somos espécies exóticas.

A perspectiva relativizadora da antropologia faz tornar-se irresistível a metáfora das espécies exóticas/invasoras ${ }^{8}$, termos, aliás, diretamente usados para designar os muitos "outros" na história deste mundo ou no mais corriqueiro dos cotidianos, conforme a posição de quem fala. A obsessão dos

\footnotetext{
${ }^{8}$ A riqueza da metáfora das espécies exóticas/invasoras é comprovada no trabalho de Comaroff e Comaroff (2001), no qual mostram como uma série de questões em torno de cidadania, comunidade e soberania nacional na "nova" África do Sul, num contexto de "pós-racismo" e de direitos civis, foi tematizada no discurso e nas "soluções" encaminhadas em diversas instâncias em relação a "invasores vegetais". Considere-se ainda, no caso do referido caramujo achatina, a eloqüência metafórica do nome vulgar que the foi atribuído: "caracol africano". Foi trazido para o Brasil para ser cultivado como o escargot, mas não deu certo: ele é escuro, grande, tem a carne dura, e tornou-se nefando; nas explicações, é comparado com o escargot, que é de tonalidade clara, arredondado, tem a carne macia, e não causa mal nenhum.
}

Horizontes Antropológicos, Porto Alegre, ano 9, n. 20, p. 205-224, outubro de 2003 
biólogos e dos técnicos ambientais com a ameaça das espécies "exóticas", "invasoras", e os danos que causam remete à idéia de que, conforme demonstrado no item anterior, para os nativos, nós todos que vamos "meter a colher lá" é que somos as espécies exóticas.

E aqui finalizo, retomando a observação inicialmente colocada a propósito dos estudos sobre turismo, no sentido de se verem de um lado propostas generalizantes referentes ao que seria, por exemplo, "um desenvolvimento turístico ideal" e, de outro, os muitos casos em que tais propostas não funcionam. A recusa, ou a resistência, dos nativos da Ilha Grande em relação ao credo ecológico ${ }^{9}$, tem uma continuidade com a resistência que igualmente manifestam em relação a certas propostas de implementação do turismo, ou do ecoturismo.

Nos casos concretos, como o que foi aqui exposto, os formuladores e proponentes das "soluções" para a "questão do turismo" com base em premissas consagradas para o tal "desenvolvimento turístico ideal" são parte de uma configuração em que vários atores sociais estão em disputa - o que nem sempre é reconhecido por tais propositores, como se essas recomendações pairassem acima de qualquer questionamento, ungidas por seu próprio conteúdo: seriam para o bem de todos. Parece ser assim sempre que se trata de algo proposto com a aura da "ecologia", do prefixo "eco" - é ecológico, é do bem; é "eco", é bom. É o caso, portanto, também da idéia do "ecoturismo", cujos promotores, na prática, parecem colocar como parte de uma "razão ecológica" inquestionável. Mas, como vimos, essa aura ecológica - nos muitos planos em que se traduz - pode ser considerada tão invasora na visão nativa como as espécies exóticas são na visão dos ecólogos.

\section{Referências}

ADAMS, Cristina. Caiçaras da mata atlântica. São Paulo: Annablume, 2000.

BOHANNAN, Laura. Miching malecho, ou seja, feitiçaria [Cadernos de Aula 1]. Rio de Janeiro: UFRJ/IFCS/Laboratório de Pesquisa Social, 1967. CALVENTE, Maria Del Carmen M. H. Ilhabela: turismo e território. In: DIEGUES, Antonio Carlos (Org.). Ilhas e sociedades insulares, 1997.

\footnotetext{
9 Venho trabalhando essa questão nos diferentes trabalhos referenciados (Prado, 2000, 2002, 2003, no prelo). Ver também Ranauro (2003).
} 
COMAROFF, Jean; COMAROFF, John. Naturalizando a nação: estrangeiros, apocalipse e o Estado pós-colonial. Horizontes Antropológicos, Porto Alegre, ano 7, n. 15, p. 57-106, jul. 2001.

DIEGUES, Antonio Carlos. O mito moderno da natureza intocada. São Paulo: Hucitec, 1998.

DIEGUES, Antonio Carlos; NOGARA, P. O nosso lugar virou parque. São Paulo: NUPAUB: CEMAR: USP, 1994.

ELIAS, Norbert; SCOTSON, John L. Os estabelecidos e os outsiders. Rio de Janeiro: Zahar, 2000.

FURLAN, Sueli Ângelo. As ilhas do litoral paulista: turismo e áreas protegidas. In: DIEGUES, Antonio Carlos (Org.). Ilhas e sociedades insulares, 1997.

GOMES, Lirandina. Praia do Forte, BA: o paraíso e suas contradições. In: RODRIGUES, Adyr Balasteri (Org.) Turismo: modernidade: globalização. São Paulo: Hucitec, 2000.

GOMES, Marcus Machado. A natureza sob vigilância: etnoecologia e ethos penitenciário na Ilha Grande. Monografia (Graduação)-Departamento de Ciências Sociais/Instituto de Filosofia e Ciências Humanas, UERJ, Rio de Janeiro, 2001.

LORENZO, Rosa Amélia Fortes Garcia. A que passos andam as tartarugas: estudo sobre o impacto sócio-cultural do turismo em Praia do Forte [GT "Ambiente, População e Cultura: Grandes Projetos e Populações Locais"]. REUNIÃO BRASILEIRA DE ANTROPOLOGIA, 20., 1996, Salvador. 1996. Mimeografado.

LUCHIARI, Maria Tereza D. P. Turismo e cultura caiçara no litoral norte paulista. In: RODRIGUES, Adyr Balasteri (Org.). Turismo: modernidade: globalização. São Paulo: Hucitec, 2000.

MELLO, Carl E. Vieira de. Apontamentos para servir à história fluminense (Ilha Grande) Angra dos Reis. Angra dos Reis: Conselho Municipal de Cultura, 1987.

PRADO, Rosane M. Depois que entrou o Imbamba: concepções de preservação ambiental entre a população da Ilha Grande [Fórum de Pesquisa "Conflitos Sócio-Ambientais e Unidades de Conservação"] In: REUNIÃO BRASILEIRA DE ANTROPOLOGIA, 22., 2000, Brasília. 2000. Mimeografado. 
PRADO, Rosane, M. Quem entende do paraíso: estudo sobre percepção e políticas ambientais num contexto de unidades de conservação [Fórum de Pesquisa: "Processos institucionais de administração de conflitos e produção de verdades no espaço público. Abordagens interdisciplinares em uma perspectiva comparada"]. In: REUNIÃO BRASILEIRA DE ANTROPOLOGIA, 23., 2002, Gramado. 2002. Mimeografado.

PRADO, Rosane M. Tensão no paraíso: aspectos da intensificação do turismo na Ilha Grande. In: CADERNO Virtual do Turismo n. 7. Rio de Janeiro: Instituto Virtual do Turismo/COPPE/UFRJ, 2003.

PRADO, Rosane M. Crentes na Ilha Grande: uma forma de ser nativo. In: BIRMAN, Patricia (Org.). Religião e espaço público. São Paulo: Attar: Pronex. No prelo.

RANAURO, Márcio Lima. "Educação ambiental pra quê?" Discurso e prática ambiental dos jovens da Brigada Mirim Ecológica da Ilha Grande. Monografia (Graduação)-Departamento de Ciências Sociais/Instituto de Filosofia e Ciências Humanas, UERJ, Rio de Janeiro, 2003.

RUSCHMANN, Doris. Turismo e planejamento sustentável: a proteção do meio ambiente. Campinas: Papirus, 2001.

SAHLINS, Marshall. Historical metaphors and mythical realities. Ann Arbor: University of Michigan Press, 1981.

SAHLINS, Marshall. Cosmologias do capitalismo. Religião e Sociedade, Rio de Janeiro, v. 16, n. 1/2, 1992.

SAHLINS, Marshall. O "pessimismo sentimental" e a experiência etnográfica: por que a cultura não é um "objeto" em via de extinção (parte I). Mana: Estudos de Antropologia Social, Rio de Janeiro, 3/2, abr. 1997.

SOUSA, Tatiana Caldeira de. Tão perto e tão longe: uma abordagem antropológica da relação entre a UERJ e a comunidade da Vila Dois Rios. Monografia (Graduação)-Departamento de Ciências Sociais/Instituto de Filosofia e Ciências Humanas, UERJ, Rio de Janeiro, 2002.

WUNDER, Sven. Big Island, green forest and backpackers, 2000. Mimeografado. 